Jurnal ELKOM diterbitkan oleh Sekolah Tinggi Elektronika dan Komputer (STEKOM). Jurnal ELKOM sebagai sarana komunikasi dan penyebarluasan hasil penelitian, pemikiran serta pengabdian pada masyarakat

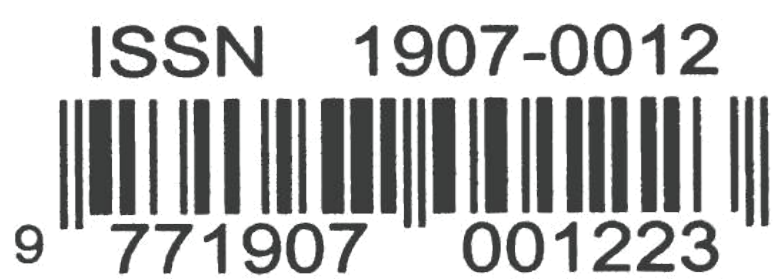

\begin{tabular}{lr}
\hline Perancangan Aplikasi Android Untuk Media Pembelajaran Budidaya Tanaman Secara \\
Hidroponik Dengan Metode Demon-Disco Leaming \\
Daniel Novianto & $1-8$ \\
\hline $\begin{array}{l}\text { Rancangan Bangun Alat Musik Piano, Harpa, Marching Bell Digital Berbasis Arduino } \\
\text { Menggunakan Cahaya Laser Dan LDR } \\
\text { Dendy Kumiawan }\end{array}$ & $9-19$ \\
\hline $\begin{array}{l}\text { Rancangan Bangun Sistem Peringatan Dini Bencana Banjir Pada Sungai Tuntang Ke- } \\
\text { dungjati Berbasis Arduino Menggunakan Teknologi IOT } \\
\text { lhsan Hidayat Ardi }\end{array}$ & $20-30$ \\
\hline $\begin{array}{l}\text { Alat Pendeteksi Gas Amoniak Pada Kamar Mandi Berbasis Arduino( Studi Kasus Diho- } \\
\text { tel Wisma Menorah Sampangan Semarang) }\end{array}$ & $31-37$ \\
\hline $\begin{array}{l}\text { Achmad Abdul Charis } \\
\text { Rancang Bangun Alat Penyotiran Barang Otomatis Berbasis Arduino Pada PT Wahana }\end{array}$ & $38-44$ \\
\hline $\begin{array}{l}\text { Prestasi Logistik Semarang } \\
\text { Yan Ilmas Puimera }\end{array}$
\end{tabular}

STEKOM

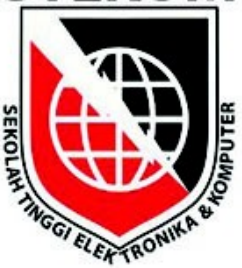

S T E K O M Sekolah Tinggi Elektronika dan Komputer SEMARANG 


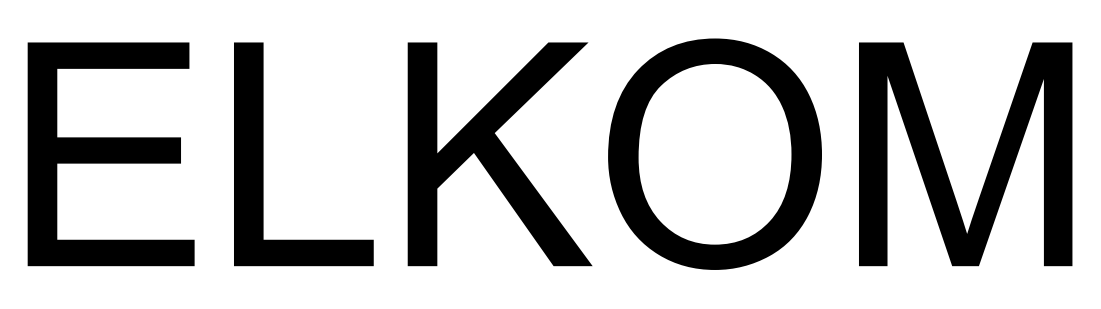

JURNAL ELEKTRONIKA DAN KOMPUTER

Penanggung Jawab :

Ketua Sekolah Tinggi Elektronika \& Komputer

Pemimpin Redaksi :

Sulartopo, S.Pd, M.Kom

Penyunting Pelaksana :

Dr. Ir. Drs. R. Hadi Prayitno, S.E, M.Pd

Dr. Ir. Agus Wibowo, M.Kom, M.Si, M.M

Sarwo Nugroho, S.Kom, M.Kom

Sekretaris Penyunting:

Ir. Paulus Hartanto, M.Kom

Mars Caroline Wibowo, S.T, MT. Tech

Sekretariat :

Dr. Unang Achlison, S.T, M.Kom

Djoko Soerjanto, S.E, M.Kom

Muhammad Sidik, S.Kom, M.Kom

Desain Grafis :

Setiyo Adi Nugroho,S.E, S.Kom

\footnotetext{
Alamat Redaksi :

Pusat Penelitian - Sekolah Tinggi Elektronika \& Komputer (STEKOM) Jl. Majapahit No. 605 Semarang Telp. 024-6710144 E-Mail :

elkom@stekom.ac.id
} 


\section{KATA PENGANTAR}

Puji syukur ke hadirat Tuhan Yang Maha Esa dengan terbitnya Jurnal elektronika dan computer (ELKOM) Edisi Desember 2018, Volume 11 Nomor 1 Tahun 2018 dengan artikel-artikel yang selalu mengikuti perkembangan IImu Pengetahuan dan Teknologi dalam bidang elektronika dan computer. Semua artikel yang dimuat pada Jurnal elektronika dan komputer (ELKOM) ini telah ditelaah oleh Dewan Redaksi yang mempunyai kompetensi di bidang elektronika dan komputer. Pada edisi ini kami menyajikan beberapa topik menarik tentang penerapan elektronika dan komputer yaitu: "Perancangan Aplikasi Android Untuk Media Pembelajaran Budidaya Tanaman Secara Hidroponik Dengan Metode Demon-Disco Learning ", serta "Rancang Bangun Alat Musik Piano, Harpa, Marching Bell Digital Berbasis Arduino Menggunakan Cahaya Laser Dan Ldr (Studi Kasus SMP NU 07 Brangsong) ", selanjutnya "Rancang Bangun Sistem Peringatan Dini Bencana Banjir Pada Sungai Tuntang Kedungjati Berbasis Arduino Menggunakan Teknologi IOT ", dan "Alat Pendeteksi Gas Amoniak Pada Kamar Mandi Berbasis Arduino (Studi kasus dihotel wisma menorah sampangan Semarang)". "Rancang Bangun Alat Penyortiran Barang Otomatis Berbasis Arduino Pada Pt Wahana Prestasi Logistik Semarang ", Terima kasih yang mendalam disampaikan kepada penulis makalah yang telah berkontribusi pada penerbitan Jurnal ELKOM edisi kali ini. Dengan rendah hati dan segala hormat, mengundang Dosen dan rekan sejawat peneliti dalam bidang elektronika dan komputer untuk mengirimkan naskah, review, gagasan dan opini untuk disajikan pada Jurnal elektronika dan komputer (ELKOM) ini. Sebagai akhir kata, saran dan kritik terhadap Jurnal elektronika dan komputer (ELKOM) yang membangun sangat diharapkan. Selamat membaca.

Semarang, Desember 2018 


\section{DAFTAR ISI}

Kata

Pengantar

Daftar

Isi. .ii

1. Perancangan Aplikasi Android Untuk Media Pembelajaran Budidaya Tanaman Secara Hidroponik Dengan Metode Demon-Disco Learning, Daniel Novianto 1-8

2. Rancang Bangun Alat Musik Piano, Harpa, Marching Bell Digital Berbasis Arduino Menggunakan Cahaya Laser Dan Ldr (Studi Kasus SMP NU 07 Brangsong), Dendy Kurniawan .9-19

3. Rancang Bangun Sistem Peringatan Dini Bencana Banjir Pada Sungai Tuntang Kedungjati Berbasis Arduino Menggunakan Teknologi IOT, Ihsan Hidayat Ardi.... 20-30

4. Alat Pendeteksi Gas Amoniak Pada Kamar Mandi Berbasis Arduino (Studi kasus dihotel wisma menorah sampangan Semarang), Achmad Abdul Charis 31-37

5. Rancang Bangun Alat Penyortiran Barang Otomatis Berbasis Arduino Pada Pt Wahana Prestasi Logistik Semarang, Yan IImas Puimera $38-44$ 

Hotel Wisma Menoreh Sampangan Semarang), Vol 11, No.1, Desember 2018.

\title{
ALAT PENDETEKSI GAS AMONIAK PADA KAMAR MANDI BERBASIS ARDUINO \\ (Studi Kasus diHotel Wisma Menoreh Sampangan Semarang)
}

\author{
Achmad Abdul Charis \\ Sekolah Tinggi Elektronika dan Komputer (STEKOM) \\ JI. Majapahit 605 \& 304 Semarang, Indonesia \\ Email : achmadcharis168@gmail.com
}

\section{Abstrak}

\begin{abstract}
Penelitian ini secara umum bertujuan untuk merancang sebuah sistem yang dapat mengatasi permasalahan di Hotel Wisma Menoreh Sampangan Semarang.Selain melakukan prosses penggunaan alat kamar mandi, diperlukan adanya sebuah pengontrol gas dalam ruang kamar mandi, terutama kadar gas amoniak dan gas lain yang ada di kamar mandi. Sistem pengontrolan kamar mandi yang ada di Hotel Wisma Menoreh Sampangan Semarang saat ini dirasa masih kurang efektif, dalam penggunaan-penggunaan alat kamar mandi tersebut kepada para tamu hotel maupun staff hotel.

Metode penelitian yang penulis gunakan adalah metode penelitian Research and Development (R\&D) yang melalui tahapan studi pendahuluan, perencanaan, pengembangan produk, ujicoba, desain produk, revisi produk, dan uji coba produk. Sistem ini dibuat dengan bahasa pemrograman Arduino.

Berdasarkan hasil analisa, alat pendeteksi gas amoniak pada kamar mandi berbasis Arduino ini dapat mengatasi permasalahan yang ada dan membantu pihak hotel dalam pengontrolan kamar mandi, baik kepada tamu maupun staff hotel dengan efektif dan efisien, serta mempermudah dalam mengelola ruangan kamar mandi yang ada di Hotel Wisma Menoreh Sampangan Semarang.
\end{abstract}

Kata kunci:Alat Pendeteksi, R\&D, Arduino, KamarMandi, Gas Amoniak

\subsection{Latar Belakang Masalah}

Seiring berjalannya waktu, perkembangan teknologi yang saat ini semakin maju tidaklah heran jika alatalat untuk memudahkan manusia ini banyak diciptakan dan dikembangkan. Tingkat polusi udara telah meningkat dengan banyak faktor seperti peningkatan populasi, transportasi, industri, dan lain sebagainya yang menghasilkan gas yang mengandung zat diatas kadar batas kewajaran serta memberikan efek bagi kesejahteraan masyarakat dan penurunan kesehatan.

Polusi udara dalam ruangan menjadi perbincangan utama setelah Environmental Protection Agency (EPA) mengumumkan bahwa polusi udara di dalam ruangan lebih berat daripada di luar ruangan. Sumber penyebab polusi udara didalam ruangan adalah bangunan itu sendiri, perlengkapan dan kondisi dalam bangunan, suhu dan kelembapan. Dilihat dari sisi kimiawi, bahan utama polusi udara antara lain Karbon Oksida $\left(\mathrm{CO}, \mathrm{CO}_{2}\right)$, Oksida Belerang $\left(\mathrm{SO}_{2}\right.$, $\left.\mathrm{SO}_{3}\right)$, Nitrogen Oksida $\left(\mathrm{NO}, \mathrm{NO}_{3}\right)$, Partikel udara (Asap, debu, metal, garam sulfat), energi panas (suhu), Hidrokarbon, dan senyawa inorganik serta kebisingan. Salah satu zat polusi udara adalah Amoniak. (EPA, 1998).

Pada usaha persewaan kamar hotel, persewaan ruang atau aula pertemuan, diperlukan adanya 

Hotel Wisma Menoreh Sampangan Semarang), Vol 11, No.1, Desember 2018.

pembaharuan ruangan hotel, terutama mengenai kamar mandi. Terkadang seseorang atau bahkan banyak orang belum bisa berlaku bijaksana dalam menggunakannya, seperti lupa menyiram air setelah digunakan dan membuang sampah tidak pada tempatnya yang menyebabkan kotornya kamar mandi. Hal ini sangat sering terjadi, terutama di tempattempat umum seperti pada hotel. Sehingga para pemilik kamar mandi tersebut seringkali menempelkan tulisan peringatan tentang anjuran untuk menjaga kebersihan dan kerapian ruangan kamar mandi setelah selesai dalam menggunakannya, tetapi masih tidak sedikit orang-orang yang mengabaikan tulisan tersebut sehingga peranan kamar mandi tetap menjadi terbelakang. Hal ini disebabkan karena belum adanya sistem yang dapat mengontrol apakah ada gas yang tidak nyaman.

Sistem kamar mandi di Hotel Wisma Menoreh Semarang juga masih dilakukan dengan cara yang konvensional dan belum terotomatisasi, yaitu dengan membuat pengontrolan otomatis kamar mandi. Sistem pengontrolan kamar mandi seperti ini juga masih memiliki beberapa kelemahan seperti modal awal yang cukup besar, apabila listrik padam sistem akan mati, selain itu jika ada beberapa kerusakan maka sistem juga akan terganggu bahkan mati.

Penelitian ini bertujuan untuk membuat Alat Pendeteksi Gas Amoniak pada Kamar Mandi Berbasis Arduino sebagai solusi dari permasalahan tersebut. Dengan dibangunnya Alat Pendeteksi Gas Amoniak pada Kamar Mandi Berbasis Arduino ini, diharapkan permasalahan yang timbul dapat terselesaikan dengan baik dan meminimalisir terjadinya suatu keadaan yang dilakukan oleh manusia serta membuat pengontrolan kadar oksigen menjadi lebih mudah.

\subsection{Rumusan Masalah}

a. Bagaimana menciptakan sebuah alat untuk mengontrol kadar gas bau urine pada kamar mandi agar dapat memberi kenyamanan pada penggunanya ?

b. Bagaimana menciptakan sebuah alat yang bisa mengendalikan dan mengatur gas bau urine diruangan kamar mandi agar dapat terkontrol dengan baik?

\subsection{Batasan Masalah}

a. Alat yang dibuat berupa alat untuk mengetahui kadar gas bau urine secara otomatis, serta memberitahukan pengguna kamar mandi secara otomatis.

b. Alat pengontrolan gas hanya akan dibuat di ruang kamar mandi tertentu.

c. Alat ini tidak mencakup suatu ruangan yang berada diluar Hotel Wisma Menoreh, dan hanya dilakukan di kamar mandi pada salah satu bagian kamar hotel ini.

\subsection{Tujuan Penelitian}

Tujuan dari dibangunnya penelitian ini adalah Alat yang otomatisakan mendeteksi gas bau urine. Selain itu, Alat Pendeteksi Gas Amoniak pada kamar mandi dengan teknologi Arduino dapat member informasi ada tidaknya kenyamanan pada kamar mandi.

\subsection{Manfaat Penelitian}

Manfaat yang diharapkan dari penelitian ini adalah terwujudnya system Terwujudnya alat pendeteksi 

Hotel Wisma Menoreh Sampangan Semarang), Vol 11, No.1, Desember 2018.

gas amoniak pada kamar mandi berbasis Arduino di Hotel Wisma Menoreh Sampangan Semarang. Serta memberikan kontribusi dalam upaya pemanfaatan kemajuan teknologi informasi dan komunikasi untuk bidang pendidikan.

\subsection{Udara}

Udara adalah salah satu larutan yang ada pada lapisan gas yang mengelilingi bumi serta komponen larutan gas tersebut tidak selalu konsisten. Udara juga atmosfir yang ada disekeliling bumi, yang kegunaannya sangat penting bagi kehidupan manusia di bumi ini.

Udara pada alam tidak pernah tidak ditemukan dalam keadaan bersih tanpa polutan. Akan tetapi, kualitas udara yang baik sangat dibutuhkan oleh manusia, dikarenakan dapat mempengaruhi dalam kesehatan manusia itu sendiri. Turunnya kualitas udara akibat terjadinya suatu polusi atau pencemaran di suatu daerah kerapkali baru dirasakan seusai dampaknya menyebabkan gangguan kesehatan pada makhluk hidup. [11]

\subsection{Sensor Gas}

Sensor gas MQ-135 merupakan sensor gas yang dapat digunakan untuk mengontrol kualitas udara untuk mendeteksi gas amoniak $\left(\mathrm{NH}_{3}\right.$ ), Nitrogen Oxside (Nox), Alkohol, Bensol, Asap, Karbon Dioxside $\left(\mathrm{CO}_{2}\right)$ dan lain-lain. Materi sensitif dari sensor gas $\mathrm{MQ}-135$ adalah $\mathrm{SNO}_{2}$. Sensor ini biasanya digunalan untuk mengukur kualitas udara.
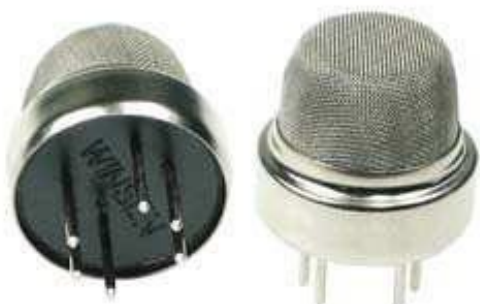

Gambar 2.1 Sensor Gas

Cara kerja dari sensor MQ-135 yaitu dengan menampilkan data analog yang terbaca dari sensor dengan cara membaca tegangan keluaran yang didapat pada saat material semikonduktor terpapar gas amoniak. Pada saat material semi konduktor $\mathrm{SnO}_{2}$ yang diberi sebuah tegangan dan panas, maka apabila terpapar gas amoniak akan terjadi perpindahan energi serta pergerakan elektron sehingga membuat tegangan keluaran mempunyai nilai berbeda dari tegangan masukan. [10]

\subsection{Kipas DC}

Motor listrik adalah perangkat elektromagnetis yang dapat mengubah energi listrik menjadi energi mekanik (gerak). Energi gerak dipergunakan untuk memutar pompa, fan, ataupun menggerakkan kompressor dan lainlain. Motor DC membutuhkan suplay tegangan yang bersamaan arah pada kumparan besi untuk diubah menjadi energi gerak. Kipas angin DC mempunyai tegangan sebesar $12 \mathrm{~V}$, dan mempunyai ukuran yang berbedabeda berkisar antara $5 \mathrm{~cm}$ sampai $12 \mathrm{~cm}$. 

Hotel Wisma Menoreh Sampangan Semarang), Vol 11, No.1, Desember 2018.

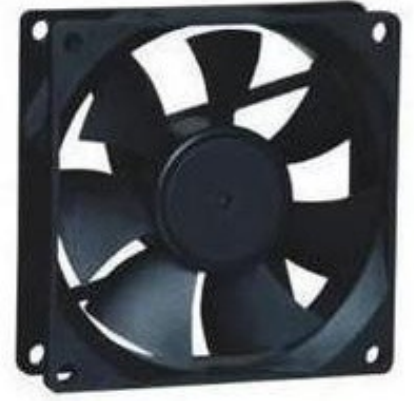

\section{Gambar 2.3 Kipas angin DC}

Dikarenakan sifat magnet saling tolak menolak pada kedua kutubnya, maka gaya tolak menolak antara kumparan besi dan sepasang magnet tersebut menjadikan gaya berputar secara teratur pada kumparan besi. Oleh karena itu, baling-baling yang ada pada kipas di sambungkan ke kumparan besi tersebut. [7]

\subsection{Mikrokontrollr Arduino}

Mikrokontroller merupakan computer didalam chip yang digunakan untuk mengontrol peralatan elektronik yang menekankan efisiensi dan efektifitas biaya. Secara harfiah bisa disebut "pengendali kecil" dimana sebuah system elektronik yang sebelumnya banyak memerlukan komponen-komponen pendukung seperti IC TTL dan CMOS dapat diperkecil dan akhirnya terpusat serta dikendalikan oleh mikrokontroller ini. [14]

a. Konsep Dasar Arduino

Co-Founder Arduino menjelaskan bahwa Arduino terdiri dari 2 komponen utama, yaitu Arduino Board yang merupakan serangkaian mikrokontroller yang telah dilengkapi berbagai soket input dan output untuk dirancang sesuai keperluan. Komponen kedua adalah Arduino IDE, sebuah software yang dijalankan pada komputer untuk mengunggah perintah program yang akan dijalankan pada Arduino. [6]

b. Hardware Arduino

Arduino adalah mikrokontroller open source, dimana tidak ada umpan balik yang hadir dalam mikrokontroller. Papan Arduino ini terdiri dari $12 \mathrm{C}$ bus yang dapat mentransfer data dari papan Arduino ke perangkat output, papan Arduino ini diprogram melalui koneksi antarmuka serial RS232 dengan mikrokontroller Arduino ATMega beroperasi sekitar 5V. Tegangan input yang direkomendasikan untuk mikrokontroller Arduino adalah dari $7 \mathrm{~V}$ dan maksimal 12V. Arus DC yang diberikan ke papan Arduino berkisar 40mA. Ini terdiri dari berbagai jenis, seperti memori flash, EEPROM, SRAM.

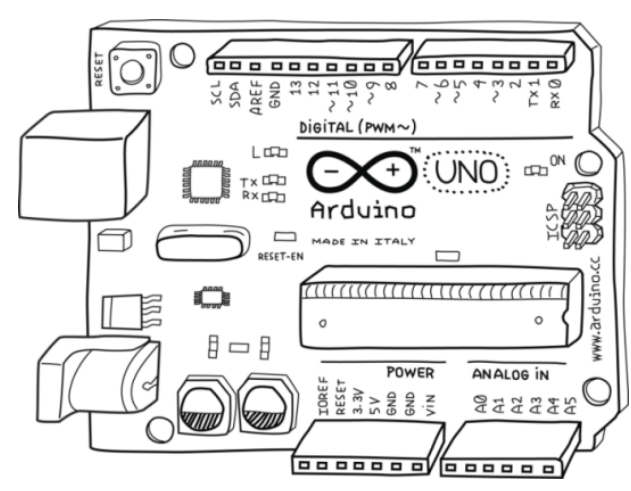

\section{Gambar 2.4 Papan Arduino}

Panjang papan Arduino sekitar $68.64 \mathrm{~mm}$ dan lebar sekitar $53.4 \mathrm{~mm}$, berat mikrokontroller adalah $20 \mathrm{~g}$. Arduino yang biasa digunakan ada berbagai jenis seperti 8 bit AVL Atmel dan 32 bit Atmel, dari berbagai jenis prosessor yang ada. Beberapa contoh penggunaan microprosessor untuk berbagai jenis proyek rekayasa serta aplikasi industri seperti mengendalikan akuator dan sensor. [12]

c. Software Arduino 

Hotel Wisma Menoreh Sampangan Semarang), Vol 11, No.1, Desember 2018.

1. Arduino diciptakan untuk para pemula bahkan yang tidak memiliki basic bahasa pemrograman sama sekali karena menggunakan bahasa $\mathrm{C}++$ yang telah dipermudah melalui library. Arduino menggunakan Software Processing yang digunakan untuk menulis program ke dalam Arduino. Processing sendiri merupakan penggabungan antara bahasa $\mathrm{C}++$ dan Java. Software Arduino ini dapat di-install di berbagai operating system (OS) seperti: LINUX, Mac OS, Windows. Software IDE Arduino terdiri dari 3 (tiga) bagian:

- Editor Program

Untuk menulis dan mengedit program dalam bahada processing. Listing program pada Arduino disebut Sketch.

- Complier

Merupakan modul yang berfungsi mengubah bahasa processing (kode program) ke dalam kode biner karena kode biner adalah satu-satunya bahasa pemrograman yang dipahami oleh mikrokontroller.

- Uploader

Modul yang berfungsi memasukkan kode biner ke dalam memori mikrokontroller.

Struktur perintah pada arduino secara garis besar terdiri dari 2 (dua) bagian yaitu void setup dan void loop. Void setup berisi perintah yang akan dieksekusi hanya satu kali sejak arduino dihidupkan sedangkan void loop berisi perintah yang akan dieksekusi berulang-ulang selama arduino dinyalakan. [12]

\subsection{Metode Pengembangan}

Pada penelitian ini, metode pengembangan yang penulis gunakan adalah metode penelitian dan pengembangan atau biasa disebut R\&D (Research and Development). Borg and Gall (1983) mengartikan penelitian dan pengembangan sebagai berikut: Penelitian dan Pengembangan (R\&D) adalah proses yang digunakan untuk mengembangkan dan memvalidasi produk penelitian. Borg and Gall mengemukakan langkah- langkah dalam penelitian dan pengembangan yang bersifat siklus seperti yang terlihat pada tabel berikut :

\section{Tabel 3.1 Langkah R\&D Borg and Gall}

\begin{tabular}{|c|c|}
\hline Langkah utama Borg and Gall & 10 Langkah Borg and Gall \\
\hline $\begin{array}{l}\text { Penelitian dan pengumpulan } \\
\text { informasi (Research and information } \\
\text { collecting) }\end{array}$ & $\begin{array}{l}\text { 1. Penelitian dan Pengumpulan } \\
\text { Informasi }\end{array}$ \\
\hline Perencanaan (Planning) & 2. Perencanaan \\
\hline $\begin{array}{l}\text { Pengembangan bentuk awal produk } \\
\text { (Develop preliminary form of } \\
\text { product) }\end{array}$ & $\begin{array}{l}\text { 3. Pengembangan bentuk awal } \\
\text { produk }\end{array}$ \\
\hline $\begin{array}{l}\text { Uji lapangan dan revisi produk } \\
\text { (Field Testing and product revision) }\end{array}$ & 4. Uji lapangan awal \\
\hline & 5. Revisi produk \\
\hline & 6. Uji lapangan utama \\
\hline & 7. Revisi produk operasional \\
\hline & 8. Uji lapangan operasional \\
\hline $\begin{array}{l}\text { Revisi produk akhir (Final product } \\
\text { revision) }\end{array}$ & 9. Revisi produk akhir \\
\hline $\begin{array}{l}\text { Diseminasi dan implementasi } \\
\text { (Dissemination and Implementation) }\end{array}$ & 10. Diseminasi dan implementasi \\
\hline
\end{tabular}

\subsection{Flowchart Sistem Lama}



Hotel Wisma Menoreh Sampangan Semarang), Vol 11, No.1, Desember 2018.

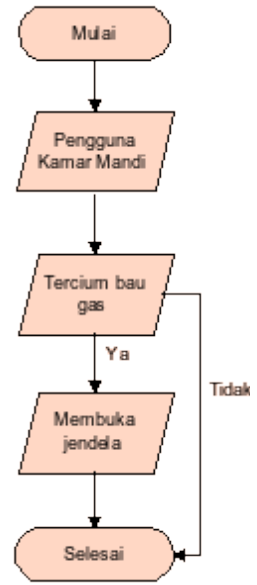

\section{Gambar 3.1 Flowchart Sistem Lama}

\subsection{Flowchart Sistem Baru}

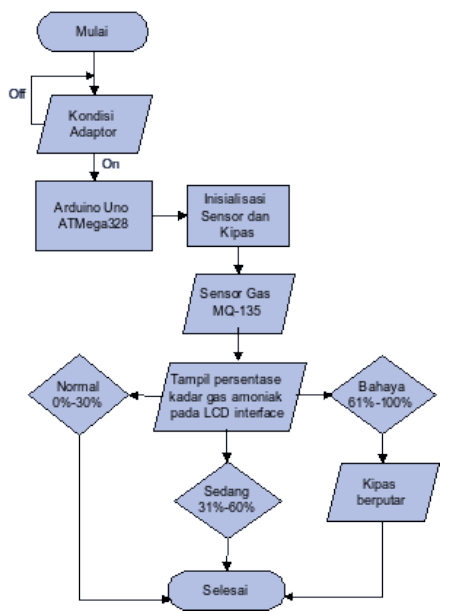

Gambar 3.2 Flowchart Sistem Baru

\subsection{Hasil Pengembangan}

Setelah melewati tahap-tahap pembuatan prototype, maka diperolehlah sebuah alat oendeteksi gas amoniak pada kamar mandi berbasis Arduino Hotel Wisma Menoreh Sampangan Semarang.

\subsection{Simpulan Tentang Produk}

Kesimpulan dari penelitian yang telah dilakukan antara lain, yaitu :

1. Dengan dibangunnya Alat Pendeteksi Gas Amoniak pada kamar mandi berbasis Arduino di Hotel Wisma Menoreh Sampangan, Semarang ini staff ataupun tamu hotel dapat ikut serta memantau kondisi kadar bau amoniak seperti bau pesing dengan cepat, mudah, dan informatif dikarenakan terdapat led melalui sistem monitoring kadar gas dan level gas pada LCD.

2. Staff maupun tamu hotel dapat mengecek apakah ruang kamar mandi berada dalam level nyaman dan tidaknya, serta ada berapakah kadar gas yang ada dalam ruangan kmar mandi tersebut serta melihat informasi melalui LCD.

\subsection{Keterbatasan Hasil produk}

Alat Pendeteksi Gas Amoniak pada kamar mandi berbasis Arduino ini masih mempunyai beberapa keterbatasan, yaitu sebagai berikut :

Ket :

$\mathbf{R}=($ Read) Terbaca

( $)=$ Berhasil

1. Alat Pendeteksi Gas Amoniak pada kamar mandi ini hanya berlaku di Hotel Wisma Menoreh Sampangan, Semarang.

2. Lama waktu yang dibutuhkan untuk membuat ruangan menjadi nyaman tidak dapat ditentukan, karena hal itu dipengaruhi adannya berbagai faktor.

3. Sistem ini sangat bergantung kepada listrik karena untuk catu daya menggunakan adaptor, sehingga apabila listrik padam, maka sistem ini tidak dapat difungsikan.

\subsection{Saran}

Berdasarkan kesimpulan diatas serta sistem yang telah dibuat, dapat diajukan beberapa saran yang dapat menjadi bahan pertimbangan dalam memanfaatkan project ini. 

Hotel Wisma Menoreh Sampangan Semarang), Vol 11, No.1, Desember 2018.

1. Sistem ini dapat dipergunakan untuk lebih dari 1 ruangan kamar mandi.

2. Letaknya harus dekat dengan sumber.

3. Dapat dilakukan Penambahan kipas untuk memberi kenyamanan dalam membuang gas amoniak yang lebih tinggi.

4. Dapat ditambahkan buzzer alarm untuk pengembangan lebih lanjut.

\section{DAFTAR PUSTAKA}

[1] Armadani, Husni. 2015. Kendali Kamar Mandi Otomatis. Yogyakarta :Universitas Gadjah Mada.

[2] Indriani, D. P. P., Yudianingsih., \& Utari, E. L. 2014. Perancangan Pulse Oximetry dengan Sistem Alarm Prioritas sebagai Vital Monitoring Terhadap Pasien, 9(27), 101.19072430. Jurnal Teknologi Informasi.

[3] Kadir, Abdul. 2013. Panduan Praktis Mempelajari Aplikasi Mikrokontroller dan Pemrograman Arduino. Yogyakarta : Andi Offset.

[4] Kadir, Abdul. 2015. From Zero to a Pro Arduino Panduan Mempelajari Aneka Proyek Berbasis Mikrokontroller. Yogyakarta : Andi Offset.

[5] KLH. 1991. Keputusan Mentri Negara Kependudukan dan Lingkungan Hidup No.KEP03/MENKLH/II/1991 Tentang Baku Mutu Limbah Cairbagi Kegiatan yang Sudah Beroperasi. Sekretariat Negara : Jakarta.

[6] Massimo, Banzi. 2014. Getting Started With Arduino 3rd Edition. USA:O'Reilly Media, Inc.

[7] McRobert, Michael. 2013. Beginning Arduino Second Edition. USA: Apress.

[8] Mulyono, Tri Widi. 2016. Otomatisasi Sistem pada Kamar Mandi Berbasis Mikrokontroller
ATMega328. Yogyakarta : Universitas Gadjah Mada.

[9] Murtiani, Titien Woro., Murtomo, B. A., Rimbowati.,Iswanto, D., \& S. Slamet, S. 1994. Kajian Perancangan Kamar Mandi Rumah Tinggal. Semarang :Universitas Diponegoro.

[10] Nugroho, Amirullah Satria. 2015. Rancang Bangun Alat Terapi untuk Mengurangi Ketergantungan Merokok Berbasis Mikrokontroller ATMega 16. Jember : Universitas Jember.

[11] Perdana, Chandra. 2015. Gambaran Asupan Amonia (NH3) pada Masyarakat Dewasa Di Kawasan Pemukiman Sekitar PT. PUSRI Palembang Tahun 2015. Universitas Islam Negeri Syarif Hidayatullah : Jakarta.

[12] Sudhan, R. H., Kumar, M. G., Prakash, A. U., RoopaDEVI, S. A., \& Satiya, P. 2015. Arduino ATMega-328 Mikrokontroller. Instrumentasi dan kontrol teknik, 3(4), 27-29. DOI : 10.17148/IJIREEICE.2015.3406 [13] Suyadhi, Taufiq D.S. 2014. LED. Robotic University.

[14] Syahwil, Muhammad. 2013. Panduan Mudah Simulasi \& Praktek Mikrokontroller Arduino. Yogyakarta : Andi Offset.

[15]United State Environmental Protection Agency (US-EPA). 1998, Indoor Air Fact No. 4 (Revisied) : Sick Building Syndrome (SBS). United State Environmental Protection Agency, Washington.

[16] Wibowo, Fatwa Yudhistira $\mathrm{H}$. 2017. Pembuatan Sistem Kontrol Gas Amonia Berbasis Mikrokontroller Arduino. Bogor : Insitut Pertanian Bogor 